\title{
Culture and Quality in Government General Hospitals in Kuwait: A Multimethod Study of their Association with the Transformational Leadership
}

\author{
Talal AlFadhala ${ }^{1}$, Hossam Elamir ${ }^{1}$, Hoda Z. Helmy ${ }^{2,3}$ \\ 1 Quality and Accreditation Directorate, Ministry of Health, Kuwait \\ 2 High Institute of Public Health, Alexandria University, Egypt \\ 3 Department of Health Services and Hospital, King Abdulaziz University, Saudi Arabia
}

\section{ABSTRACT}

Background Although there are many healthcare leaders and an ongoing quality programme in the national healthcare system in Kuwait, study of the relationship of leadership style to organisational culture and quality of care is lacking.

Methods We report a multi-centre study that used cross-sectional and retrospective quantitative approaches in the government-sponsored secondary care setting in Kuwait. A sample of 1,626 was drawn from a frame of 9,863 physicians, nurses, and pharmacists in 6 general hospitals. Followers were surveyed using the Multifactor Leadership and the Organizational Description Questionnaires. We reviewed and analysed the past one year of quarterly and annual quality indicators of the studied hospitals. Data were analysed using Statistical Package for the Social Sciences (SPSS) Version 15.0.

Results According to followers, $66.4 \%$ to $87.1 \%$ of participants in the six hospitals identified their hospital organisational culture as transformational, while 41 out of 48 departments were identified as having a transformational culture. The participants who rated their leader and organisational culture as transformational ranged from $60.5 \%$ to $80.4 \%$ in different hospitals, and $8.5 \%$ of participants in only 1 hospital scored their leader as transformational and their culture as transactional. The differences between leadership style and organizational culture were statistically significant for four hospitals. Regarding the quality indicators, there was an indirect non-significant correlation between a transformational leadership style and most hospitals' indicators.

Conclusions Transformational leaders are definers and givers of culture. The prevailing transformational leadership style creates and maintains the kind of transformational organisational culture. Our work here indicates how a given leadership style affects statistics of 
medRxiv preprint doi: https://doi.org/10.1101/2020.07.15.20154245; this version posted July 16, 2020. The copyright holder for this preprint (which was not certified by peer review) is the author/funder, who has granted medRxiv a license to display the preprint in perpetuity.

It is made available under a CC-BY-ND 4.0 International license .

indicators that reflect the quality of care delivery observed in hospitals. However, this relationship is statistically insignificant. This relationship needs further research.

\section{INTRODUCTION}

In healthcare organisations, nothing plays as significant role in concurrently shaping the organisational culture, improving care quality, and enhancing patient safety as leadership.[1-3] Different leadership styles are demonstrated by healthcare executives, directors, and managers to influence their followers in healthcare organisations. Classical leadership (situational/ laissezfaire) and contemporary leadership (transactional/ transformational) styles are examples and they impact leaders' roles.[3-6] The style that leaders approximate or choose is based on a combination of their beliefs, values and performance, with contributions from organisational culture and norms, which encourage some leadership styles and discourage others.[3,7]

Transformational leaders can help to develop, shape, and maintain a desired organisational culture. They do so by creating and infusing the values, beliefs, and perceptions that they believe are necessary and good for the organisation.[3,8] When strong and unified values, beliefs, and perceptions develop, a strong organisational culture emerges.[9,10] Organisational culture is defined as the shared basic assumptions learned by staff that distinguish their organisation from other similar entities. It is manifested in some characteristics as organisational innovation and learning. $[9,10]$ Organisational culture is a variable that significantly influences organisational outcomes, itself influenced by leaders' interactions with followers, their approach problems, reaction to competition, and implementation of new strategies.[3,11] This in return ensures consistent behaviour between members of healthcare organisations that reduce conflicts and create healthy working environments for employees.[3,12]

Quality of care is an indispensable component of healthcare organisation performance. $[8,13]$ It depends on many factors such as planning and provision of services that meet the patient needs, acquiring and allocating resources, providing sufficient staff, nurturing a culture that fosters quality and safety, and setting priorities for improvement. $[4,8,14]$ The World Health Organization identifies quality healthcare services as being effective, safe, and people- 
medRxiv preprint doi: https://doi.org/10.1101/2020.07.15.20154245; this version posted July 16, 2020. The copyright holder for this preprint (which was not certified by peer review) is the author/funder, who has granted medRxiv a license to display the preprint in perpetuity.

It is made available under a CC-BY-ND 4.0 International license .

centred.[15] Only healthcare leaders have the resources and control to exhibit characteristics that influence and support quality and safety.[3,14,16] Healthcare quality can be assessed by quality indicators, quantitative measures used to evaluate and monitor the quality of processes of care, customer service, and different aspects of the organisation that are known to contribute to its quality outcomes.[17] Generic quality indicators are one type that measures aspects of care relevant to most patients regardless of their diagnosis or care setting.[18,19]

This paper is the second of three papers reporting the findings of a research project that assesses leadership styles, organisational culture, patient safety initiatives, and quality of care in six government general hospitals in Kuwait. Acknowledging that this field is under-researched in the region despite its high importance and quantified and large impact,[17,20] the purpose of this paper is to explore and assess the organisational culture and the quality of care, respectively, and measure the association of a transformational/transactional leadership style in the studied hospitals. The first paper reported the leadership styles in the six government general hospitals,[20] and the third and last one will comment on the reported incidents, reporting practices, and patient safety initiatives and their relationship with the leadership style.

\section{METHODS}

\section{Setting}

This is a multi-centre study conducted at all six government general hospitals in Kuwait. The hospitals were coded by using the first six alphabetical letters A, B, C, D, E, and F. At the time of data collection, the government healthcare system in Kuwait was providing the majority of secondary healthcare services at these six general acute care hospitals.[20] Hospital bed counts ranged between 398 and 866, with a total capacity of 3,517 beds.[21] The six hospitals have these clinical and allied health departments: medicine, surgery, paediatrics, ICU, Accidents and Emergency (A\&E), laboratory, nursing, and pharmacy.

\section{Study population and sampling}

The study population consisted of 9,863 individuals representing these professions: physicians, nurses, and pharmacists. Any subject who spent less than one year in the hospital was excluded. Investigators preferred that followers should have direct contact with their respective 
medRxiv preprint doi: https://doi.org/10.1101/2020.07.15.20154245; this version posted July 16, 2020. The copyright holder for this preprint (which was not certified by peer review) is the author/funder, who has granted medRxiv a license to display the preprint in perpetuity.

It is made available under a CC-BY-ND 4.0 International license .

leader, and thus we excluded trainees and assistant registrar physicians and technicians. The population size of professionals in all categories in the six hospitals ranged between 1,448 and 1,961. Based on a previous study on leadership styles,[22] the required sample size was calculated to be 271 per hospital using STATA 10. The calculation was done assuming:

1. A mean score of employees' perception of their leader as a transformer $=24.62$

2. A standard deviation $(\mathrm{SD})$ of $=8.81$, accepted error $=1.5$

3. An alpha of 0.05 and power of $80 \%$.[23]

Physicians in each hospital from different departments, nurses, and pharmacists were selected using proportional allocation. As nurses usually have different rotation schedules by the department, the sample was randomly selected in each hospital from all departments.

\section{Study instrument and data collection}

This is a multi-method study conducted with cross-sectional and retrospective quantitative approaches. A period of one month in 2013 was spent in each hospital for collecting data from followers using two self-administered questionnaires: the Multifactor Leadership Questionnaire and the Organizational Description Questionnaire.[24,25] The two questionnaires have two versions, one to be answered by the leader, the other is for followers. In this paper, survey respondents will be referred to as followers.

The retrospective quantitative approach reviewed and included the statistics on all Generic Quality Indicators in each studied hospital for the year 2012.[26] These indicators were used as a measure of the quality of care in the government hospital in Kuwait. The indicators were developed by the Quality and Accreditation Directorate in 2002 for use in all government hospitals in Kuwait. They are:

a. Percentage of patients discharged against medical advice in inpatient departments.

b. Percentage of elective operations cancelled on the day of, or after, admission.

c. Unscheduled return to operating theatre within 48 hours during the same hospital admission.

d. Percentage of the length of stay for appendectomy operation of five days and over.

e. Percentage of patients discharged from the general surgical department without undergoing an operation.

\section{Ethical considerations}


medRxiv preprint doi: https://doi.org/10.1101/2020.07.15.20154245; this version posted July 16, 2020. The copyright holder for this preprint (which was not certified by peer review) is the author/funder, who has granted medRxiv a license to display the preprint in perpetuity. It is made available under a CC-BY-ND 4.0 International license .

The Standing Committee for Coordination of Health and Medical Research in Kuwait granted ethical approval to conduct this study. Participating hospitals provided permission for the study and hospital and respondent identities were coded to ensure anonymity and kept confidential. Participants provided voluntary verbal informed consent after an explanation of the study's value, benefits, and risks and their questions were satisfactorily answered.

\section{Data management and analysis}

Transactional and transformational leadership style and organisational culture scores were calculated as indicated by the Multifactor Leadership Questionnaire and the Organizational Description Questionnaire sets.[24,25] The larger score indicated whether it is a transactional or transformational leadership style or organisational culture.[24,25] The scores for both questionnaires were calculated as follow:

\section{I. $\quad$ Multifactor Leadership Questionnaire scoring:}

The Multifactor Leadership Questionnaire is rated on a five-point scale:

$0=$ Not at all, $1=$ Once in a while, $2=$ Sometimes, $3=$ Fairly often, and $4=$ Frequently, if not always.

Calculation of the mean score of leadership styles was done through formula 1 and 2 as follow:

- Formula 1: Mean score of leadership factor= Score of all respondents on items related to a specific leadership factor Number of items for the same factor $X$ Number or respondents

- Formula 2: Mean score of each leadership style= Sum of the mean scores of leadership factors related to a specific leadership factor Number of factors for the same leadership style

\section{Organizational Description Questionnaire scoring:}

- Transactional culture score: add one for each odd-numbered statement marked as true and subtract one for each odd-numbered statement marked as false.

- $\quad$ Transactional culture score $=$ Total of odd-numbered statements that were true - Total of odd-numbered statements that were false

- Transformational culture score: add one for each even-numbered statement marked as true and subtract one for each even-numbered statement marked as false.

- $\quad$ Transformational culture score $=$ Total of even-numbered statements that were true Total of even-numbered statements that were false 
medRxiv preprint doi: https://doi.org/10.1101/2020.07.15.20154245; this version posted July 16, 2020. The copyright holder for this preprint

- $\quad$ The indecisive or cannot say statements (?) was scored as zero.

- The larger score indicated whether it is transactional or transformational culture.

SPSS 15.0 was used in data analysis. The $\mathrm{p} \leq 0.05$ was used as the cut off value for statistical significance (p-value). The following statistical measures were used:

III. Descriptive statistics:

1. Count and percentage: Used for describing and summarizing qualitative data.

2. Minimum, maximum, arithmetic mean ( $\mathrm{x} \square$ ), standard deviation (SD): Used as measures of central tendency and dispersion, respectively, for normally distributed quantitative data.

IV. Inferential/Non-Inferential Statistics:

1. Chi-Square $\left(x^{2}\right)$ : Used to test the association between two qualitative variables or to detect the difference between two or more proportions.

2. Monte Carlo Exact Test: Used when $x^{2}$ is not valid (> 20\% of the expected cells have a count less than 5) and for tables larger than $2 \times 2$.

3. t-test: Used to compare two sample means:

a. The pooled variance t-test: If the variances of the two groups are equal.

b. The separate variance t-test: If the variances of the two groups are not equal.

c. Levene test: is used to test the hypothesis that the two population variances are equal.

4. One-way analysis of variance (ANOVA): Used for testing the differences between more than two groups' means.

5. Simple correlation (Pearson's r): Measures the degree of association between two quantitative variables. Values of $\mathrm{r}$ range between (-1) and (+1). A positive sign means the relationship is direct, indicating that an increase in one variable is associated with an increase in the other variable and a decrease in one variable is associated with a decrease in the other variable. A negative sign means there is an inverse or indirect relationship between the two variables which means an increase in one variable is associated with a decrease in the other. If $\mathrm{r}=$ zero, this means no association or correlation between the two variables.

6. McNemar's chi-square test: Used for assessing the differences in the organizational culture styles as rated by followers.

\section{RESULTS}


medRxiv preprint doi: https://doi.org/10.1101/2020.07.15.20154245; this version posted July 16, 2020. The copyright holder for this preprint (which was not certified by peer review) is the author/funder, who has granted medRxiv a license to display the preprint in perpetuity. It is made available under a CC-BY-ND 4.0 International license .

Results of the complete analysis of the Multifactor Leadership Questionnaire are not included in the scope of this paper as they were reported in a previously published article.[20] Table 1 displays the relevant part which shows that "all followers rated their leaders as transformational leaders, except the followers of the head of pharmacy in hospital A and the head of surgery in hospital C, who rated their leaders as transactional” (page 463).[20] It is worthy to point that followers rated their transformational leaders with lower scores than the leaders' self-rating, except for the heads of medicine in Hospitals A and E. The same was true of heads of ICU, A\&E, and Laboratory in Hospitals B, E, and C respectively. This is of importance which will be discussed later.

Comparing the organisational cultures among the studied hospitals, Hospital D had the most transformational organisational culture style (87.1\%), followed by Hospital C and F (80.1\% and $75.3 \%$, respectively) (Table 2). The lowest rating was noted in Hospital B (66.4\%). Departmental organisational culture styles were mainly transformational except in Surgery, Intensive Care Unit, and Pharmacy in Hospital E (52.9\%, 55.6\%, and 75.0\% respectively); A\&E and Laboratory in Hospital D (60.0\% and 66.7\%); and Medicine in Hospital B (59.1\%). In Hospital C, transformational and transactional styles were equally represented in the Pharmacy department (50\% each).

Table 3 indicates that the percentage of followers who believed that they have a transformational leader and an organisational culture combined ranged from $60.5 \%$ for Hospital B to $80.4 \%$ for Hospital D. The percentage of followers who believed that they have a transactional leader, as well as a transactional organisational culture, ranged from $4.1 \%$ for Hospital E to $7.7 \%$ for Hospital A and B. However, the percentage of followers who believed that they have a transformational leader, but rated their organisational culture as transactional ranged from $8.5 \%$ in Hospital D to $25.8 \%$ in Hospital B. The differences between leadership style and organisational culture were statistically significant for the four Hospitals A, B, E, and F; with p-values of $\leq 0.001, \leq 0.001,0.002$, and 0.002 , respectively.

Table 4 shows the 2012 generic quality indicator results in the six studied hospitals. Hospital $\mathrm{F}$ had the highest percentage of discharges against medical advice (7.9\%) while 
medRxiv preprint doi: https://doi.org/10.1101/2020.07.15.20154245; this version posted July 16, 2020. The copyright holder for this preprint (which was not certified by peer review) is the author/funder, who has granted medRxiv a license to display the preprint in perpetuity. It is made available under a CC-BY-ND 4.0 International license.

Hospital B had the lowest (1\%). Hospital B had the highest percentages of cancelled operations (12.9\%) and Hospital D had the lowest (9.3\%). For the number of cases of unscheduled return for operations, Hospital A (56 cases) had the highest number of cases and Hospital C (9 cases) had the lowest. Hospital C (46.6\%) had the highest percentage of the length of stay for appendectomy longer than five days and Hospital D (14.1\%) had the lowest. Regarding the percentage of discharge from the surgical department without an operation, Hospital D had the highest percentage (54.5\%) and Hospital E had the lowest percentage (32.3\%).

Table 5 shows the relationship between generic quality indicators and transformational leadership style of heads of departments in the six studied hospitals. The correlation between transformational leadership style with both the percentage of discharge against medical advice and percentage of the length of stay for appendectomy longer than five days were very weak, nearly null, indirect, and non-significant $(\mathrm{r}=-0.03, \mathrm{p}=0.957$ and $\mathrm{r}=-0.09, \mathrm{p}=0.872$ respectively). For the correlation between transformational leadership style of heads of departments with the percentage of cancelled operations $(r=-0.37, p=0.468)$ and the number of unscheduled return for operations $(\mathrm{r}=-0.71, \mathrm{p}=0.111)$ were moderate, indirect, and nonsignificant. The correlation between transformational leadership style of heads of departments and the percentage of discharge from the surgical department without operation was moderate, direct, and non-significant $(\mathrm{r}=0.49, \mathrm{p}=0.329)$. 
Table 1: Mean scores of leadership styles according to followers' rating and self-rating in all hospitals (adapted from Table 1 Page 364).[20] The larger mean score of transformational (TFL) or transactional (TAL) factors indicates the leadership style is transformational or transactional.

\begin{tabular}{|c|c|c|c|c|c|c|c|c|c|c|c|c|c|c|c|c|c|c|c|}
\hline \multirow{2}{*}{ 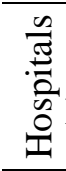 } & \multirow{2}{*}{$\begin{array}{l}\text { Leadership } \\
\text { style }\end{array}$} & \multicolumn{2}{|c|}{ Director } & \multicolumn{2}{|c|}{ Medicine } & \multicolumn{2}{|c|}{ Surgery } & \multicolumn{2}{|c|}{ Paediatrics } & \multicolumn{2}{|c|}{ ICU } & \multicolumn{2}{|c|}{$\mathrm{A} \& \mathrm{E}$} & \multicolumn{2}{|c|}{ Laboratory } & \multicolumn{2}{|c|}{ Nursing } & \multicolumn{2}{|c|}{ Pharmacy } \\
\hline & & FR & SR & FR & SR & FR & SR & FR & SR & FR & SR & FR & SR & FR & SR & FR & SR & FR & SR \\
\hline \multirow[t]{2}{*}{ A } & TFL & $\begin{array}{c}2.74 \pm \\
1.09\end{array}$ & 2.75 & $\begin{array}{c}3.27 \pm \\
0.61\end{array}$ & 3.20 & $\begin{array}{c}2.86 \pm \\
0.81\end{array}$ & 3.65 & $\begin{array}{c}2.45 \pm \\
0.85\end{array}$ & 3.40 & $\begin{array}{c}3.29 \pm \\
0.39\end{array}$ & 3.55 & $\begin{array}{c}3.03 \pm \\
0.4\end{array}$ & 3.45 & $\begin{array}{c}3.03 \pm \\
0.5\end{array}$ & 3.60 & $\begin{array}{c}2.79 \pm \\
0.62\end{array}$ & 3.45 & $\begin{array}{c}2.33 \pm \\
0.6\end{array}$ & 3.8 \\
\hline & TAL & $\begin{array}{c}2.16 \pm \\
0.53\end{array}$ & 2.0 & $\begin{array}{c}2.5 \pm \\
0.5\end{array}$ & 2.67 & $\begin{array}{c}2.31 \pm \\
0.59\end{array}$ & 2.0 & $\begin{array}{c}2.16 \pm \\
0.45\end{array}$ & 2.58 & $\begin{array}{c}2.57 \pm \\
0.38\end{array}$ & 2.50 & $\begin{array}{c}2.39 \pm \\
0.46\end{array}$ & 2.17 & $\begin{array}{c}2.58 \pm \\
0.36\end{array}$ & 2.50 & $\begin{array}{c}2.25 \pm \\
0.50\end{array}$ & 2.25 & $\begin{array}{c}2.52 \pm \\
0.32\end{array}$ & 2.83 \\
\hline \multirow[t]{2}{*}{ B } & TFL & $\begin{array}{c}2.76 \pm \\
0.82\end{array}$ & 3.35 & $\begin{array}{c}2.51 \pm \\
0.71\end{array}$ & 3.5 & $\begin{array}{c}2.35 \pm \\
0.62\end{array}$ & 3.6 & $\begin{array}{c}2.60 \pm \\
0.95\end{array}$ & 4.0 & $\begin{array}{c}2.93 \pm \\
0.69\end{array}$ & 2.40 & $\begin{array}{c}2.23 \pm \\
0.94\end{array}$ & 4.0 & $\begin{array}{c}2.51 \pm \\
1.10\end{array}$ & 3.05 & $\begin{array}{c}2.67 \pm \\
0.66\end{array}$ & 3.0 & $\begin{array}{c}2.74 \pm \\
0.53\end{array}$ & 3.45 \\
\hline & TAL & $\begin{array}{c}2.44 \pm \\
0.46\end{array}$ & 2.33 & $\begin{array}{c}1.98 \pm \\
0.34\end{array}$ & 2.58 & $\begin{array}{c}2.06 \pm \\
0.37\end{array}$ & 2.50 & $\begin{array}{c}2.10 \pm \\
0.48\end{array}$ & 2.83 & $\begin{array}{c}2.31 \pm \\
0.28\end{array}$ & 2.58 & $\begin{array}{c}2.13 \pm \\
0.41\end{array}$ & 2.67 & $\begin{array}{c}2.0 \pm \\
0.41\end{array}$ & 25 & $\begin{array}{c}2.18 \pm \\
0.45\end{array}$ & 2.42 & $\begin{array}{c}2.21 \pm \\
0.72\end{array}$ & 2.58 \\
\hline \multirow[t]{2}{*}{$\mathrm{C}$} & TFL & $\begin{array}{c}2.41 \pm \\
0.94\end{array}$ & 3.75 & $\begin{array}{c}2.93 \pm \\
0.55\end{array}$ & 3.0 & $\begin{array}{c}2.07 \pm \\
1.0\end{array}$ & 3.50 & $\begin{array}{c}2.95 \pm \\
0.39\end{array}$ & 3.55 & $\begin{array}{c}3.18 \pm \\
0.48\end{array}$ & 3.55 & $\begin{array}{c}3.34 \pm \\
0.64\end{array}$ & 3.40 & $\begin{array}{c}3.26 \pm \\
0.47\end{array}$ & 3.15 & $\begin{array}{c}2.60 \pm \\
0.54\end{array}$ & 3.25 & $\begin{array}{c}2.76 \pm \\
0.58\end{array}$ & 3.45 \\
\hline & TAL & $\begin{array}{c}2.08 \pm \\
0.68\end{array}$ & 2.0 & $\begin{array}{c}2.37 \pm \\
0.51\end{array}$ & 1.75 & $\begin{array}{c}2.23 \pm \\
0.44\end{array}$ & 1.92 & $\begin{array}{c}2.08 \pm \\
0.35\end{array}$ & 2.25 & $\begin{array}{c}2.55 \pm \\
0.41\end{array}$ & 2.50 & $\begin{array}{c}2.50 \pm \\
0.39\end{array}$ & 2.33 & $\begin{array}{c}2.36 \pm \\
0.45\end{array}$ & 1.58 & $\begin{array}{c}1.90 \pm \\
0.14\end{array}$ & 3.0 & $\begin{array}{c}2.19 \pm \\
0.48\end{array}$ & 2.17 \\
\hline \multirow[t]{2}{*}{ D } & TFL & $\begin{array}{c}3.13 \pm \\
0.29\end{array}$ & 3.45 & $\begin{array}{c}2.96 \pm \\
0.67\end{array}$ & 3.15 & $\begin{array}{c}2.45 \pm \\
0.52\end{array}$ & 3.55 & $\begin{array}{c}3.32 \pm \\
0.27\end{array}$ & 3.70 & $\begin{array}{c}3.20 \pm \\
0.58\end{array}$ & 3.55 & $\begin{array}{c}2.49 \pm \\
0.75\end{array}$ & 3.25 & $\begin{array}{c}3.08 \pm \\
0.25\end{array}$ & 3.80 & $\begin{array}{c}2.80 \pm \\
0.61\end{array}$ & 3.70 & $\begin{array}{c}3.13 \pm \\
0.3\end{array}$ & 3.50 \\
\hline & TAL & $\begin{array}{c}2.38 \pm \\
0.23\end{array}$ & 2.0 & $\begin{array}{c}2.29 \pm \\
0.52\end{array}$ & 2.25 & $\begin{array}{c}2.17 \pm \\
0.23\end{array}$ & 2.67 & $\begin{array}{c}2.68 \pm \\
0.44\end{array}$ & 2.08 & $\begin{array}{c}2.15 \pm \\
0.48\end{array}$ & 2.58 & $\begin{array}{c}2.43 \pm \\
0.26\end{array}$ & 2.33 & $\begin{array}{c}1.78 \pm \\
0.27\end{array}$ & 2.33 & $\begin{array}{c}2.13 \pm \\
0.44\end{array}$ & 2.58 & $\begin{array}{c}2.25 \pm \\
0.29\end{array}$ & 2.58 \\
\hline \multirow[t]{2}{*}{ E } & FL & $\begin{array}{c}1.94 \pm \\
0.67\end{array}$ & 3.0 & $\begin{array}{c}3.01 \pm \\
0.71\end{array}$ & 3.0 & $\begin{array}{c}2.62 \pm \\
0.7\end{array}$ & 3.50 & $\begin{array}{c}2.65 \pm \\
0.67\end{array}$ & 3.05 & $\begin{array}{c}2.81 \pm \\
0.55\end{array}$ & 3.75 & $\begin{array}{c}2.79 \pm \\
0.6\end{array}$ & 2.0 & $\begin{array}{c}2.77 \pm \\
0.83\end{array}$ & 3.80 & $\begin{array}{c}2.64 \pm \\
0.74\end{array}$ & 3.75 & $\begin{array}{c}3.29 \pm \\
0.44\end{array}$ & 3.80 \\
\hline & TAL & $\begin{array}{c}1.86 \pm \\
0.34\end{array}$ & 1.83 & $\begin{array}{l}2.4 \pm \\
0.46\end{array}$ & 1.83 & $\begin{array}{c}2.14 \pm \\
0.3\end{array}$ & 1.92 & $\begin{array}{c}2.25 \pm \\
0.56\end{array}$ & 1.75 & $\begin{array}{c}2.15 \pm \\
0.5\end{array}$ & 2.67 & $\begin{array}{c}2.43 \pm \\
0.52\end{array}$ & 2.0 & $\begin{array}{c}2.55 \pm \\
0.46\end{array}$ & 2.17 & $\begin{array}{c}2.22 \pm \\
0.64\end{array}$ & 2.17 & $\begin{array}{c}3.0 \pm \\
0.30\end{array}$ & 2.17 \\
\hline \multirow[t]{2}{*}{$\mathrm{F}$} & TFL & $\begin{array}{c}2.80 \pm \\
0.81\end{array}$ & 3.35 & $\begin{array}{c}3.46 \pm \\
0.13\end{array}$ & 3.75 & $\begin{array}{c}2.37 \pm \\
0.86\end{array}$ & 3.90 & $\begin{array}{c}3.09 \pm \\
0.74\end{array}$ & 3.70 & $\begin{array}{c}3.26 \pm \\
0.44\end{array}$ & 3.50 & $\begin{array}{c}2.72 \pm \\
1.0\end{array}$ & 3.25 & $\begin{array}{c}2.75 \pm \\
0.36\end{array}$ & 2.0 & $\begin{array}{c}2.60 \pm \\
0.6\end{array}$ & 3.30 & $\begin{array}{c}2.88 \pm \\
0.53\end{array}$ & 3.45 \\
\hline & TAL & $\begin{array}{c}2.39 \pm \\
0.56\end{array}$ & 2.33 & $\begin{array}{c}2.38 \pm \\
0.19\end{array}$ & 1.42 & $\begin{array}{c}2.19 \pm \\
0.53\end{array}$ & 2.17 & $\begin{array}{c}2.43 \pm \\
0.59\end{array}$ & 2.33 & $\begin{array}{c}2.46 \pm \\
0.32\end{array}$ & 2.83 & $\begin{array}{c}2.21 \pm \\
0.62\end{array}$ & 2.25 & $\begin{array}{c}2.04 \pm \\
0.27\end{array}$ & 2.0 & $\begin{array}{c}2.12 \pm \\
0.41\end{array}$ & 2.67 & $\begin{array}{c}2.24 \pm \\
0.53\end{array}$ & 1.42 \\
\hline
\end{tabular}

FR: Followers' rating

SR: Self-rating 
Table 2: Organizational Culture Styles Based on the Followers' Rating in Departments of the Six Studied Hospitals

\begin{tabular}{|c|c|c|c|c|c|c|c|c|c|c|c|c|c|}
\hline \multirow[t]{3}{*}{ Department } & \multirow{3}{*}{$\begin{array}{l}\text { Organizational } \\
\text { culture style }\end{array}$} & \multicolumn{12}{|c|}{ Hospital } \\
\hline & & \multicolumn{2}{|c|}{$\mathrm{A}(\mathrm{n}=271)$} & \multicolumn{2}{|c|}{$\mathrm{B}(\mathrm{n}=271)$} & \multicolumn{2}{|c|}{$C(n=271)$} & \multicolumn{2}{|c|}{$\mathrm{D}(\mathrm{n}=271)$} & \multicolumn{2}{|c|}{$E(n=271)$} & \multicolumn{2}{|c|}{$\mathrm{F}(\mathrm{n}=271)$} \\
\hline & & No. & $\%$ & No. & $\%$ & No. & $\%$ & No. & $\%$ & No. & $\%$ & No. & $\%$ \\
\hline \multirow{2}{*}{ Medicine } & Transformational & 15 & 83.3 & 9 & 40.9 & 19 & 79.2 & 19 & 90.5 & 21 & 84.0 & 7 & 77.8 \\
\hline & Transactional & 3 & 16.7 & 13 & 59.1 & 5 & 20.8 & 2 & 9.5 & 4 & 16.0 & 2 & 22.2 \\
\hline \multirow{2}{*}{ Surgery } & Transformational & 8 & 61.5 & 11 & 57.9 & 6 & 66.7 & 6 & 85.7 & 8 & 47.1 & 7 & 53.8 \\
\hline & Transactional & 5 & 38.5 & 8 & 42.1 & 3 & 33.3 & 1 & 14.3 & 9 & 52.9 & 6 & 46.2 \\
\hline \multirow{2}{*}{ Paediatrics } & Transformational & 15 & 68.2 & 10 & 83.3 & 10 & 62.5 & 9 & 90.0 & 27 & 73.0 & 17 & 81.0 \\
\hline & Transactional & 7 & 31.8 & 2 & 16.7 & 6 & 37.5 & 1 & 10.0 & 10 & 27.0 & 4 & 19.0 \\
\hline \multirow{2}{*}{$\begin{array}{l}\text { Intensive } \\
\text { Care Unit }\end{array}$} & Transformational & 6 & 75.0 & 6 & 66.7 & 8 & 80.0 & 5 & 100.0 & 4 & 44.4 & 9 & 90.0 \\
\hline & Transactional & 2 & 25.0 & 3 & 33.3 & 2 & 20.0 & 0 & 0.0 & 5 & 55.6 & 1 & 10.0 \\
\hline \multirow{2}{*}{$A \& E$} & Transformational & 6 & 60.0 & 5 & 55.6 & 6 & 100.0 & 2 & 40.0 & 7 & 70.0 & 4 & 57.1 \\
\hline & Transactional & 4 & 40.0 & 4 & 44.4 & 0 & 0.0 & 3 & 60.0 & 3 & 30.0 & 3 & 42.9 \\
\hline \multirow{2}{*}{ Laboratory } & Transformational & 3 & 100.0 & 5 & 71.4 & 6 & 85.7 & 1 & 33.3 & 4 & 80.0 & 6 & 75.0 \\
\hline & Transactional & 0 & 0.0 & 2 & 28.6 & 1 & 14.3 & 2 & 66.7 & 1 & 20.0 & 2 & 25.0 \\
\hline \multirow{2}{*}{ Nursing } & Transformational & 141 & 73.4 & 130 & 69.9 & 160 & 82.1 & 189 & 87.9 & 126 & 76.8 & 150 & 76.1 \\
\hline & Transactional & 51 & 26.6 & 56 & 30.1 & 35 & 17.9 & 26 & 12.1 & 38 & 23.2 & 47 & 23.9 \\
\hline \multirow{2}{*}{ Pharmacy } & Transformational & 3 & 60.0 & 4 & 57.1 & 2 & 50.0 & 5 & 100.0 & 1 & 25.0 & 4 & 66.7 \\
\hline & Transactional & 2 & 40.0 & 3 & 42.9 & 2 & 50.0 & 0 & 0.0 & 3 & 75.0 & 2 & 33.3 \\
\hline \multirow[b]{2}{*}{ Total } & Transformational & 197 & 72.7 & 180 & 66.4 & 217 & 80.1 & 236 & 87.1 & 198 & 73.1 & 204 & 75.3 \\
\hline & Transactional & 74 & 27.3 & 91 & 33.6 & 54 & 19.9 & 35 & 12.9 & 73 & 26.9 & 67 & 24.7 \\
\hline
\end{tabular}


Table 3: Relationship between organizational culture and heads of departments' leadership style based on followers' rating

\begin{tabular}{ccccccccc}
\hline Hospital & Organizational & \multicolumn{3}{c}{ Heads of departments leadership style } & \multicolumn{2}{c}{ Total } & McNemar \\
& culture & \multicolumn{2}{c}{ Transformational } & \multicolumn{2}{c}{ Transactional } & & & $\mathrm{p}^{* 1}$ \\
& & No. & $\%$ & No. & $\%$ & No. & $\%$ & \\
\hline A & Transformational & 175 & 64.6 & 22 & 8.1 & 197 & 72.7 & \\
$(\mathrm{n}=271)$ & Transactional & 53 & 19.6 & 21 & 7.7 & 74 & 27.3 & $\leq 0.001$ \\
& Total & 228 & 84.1 & 43 & 15.9 & 271 & 100.0 & \\
B & Transformational & 164 & 60.5 & 16 & 5.9 & 180 & 66.4 & \\
$(\mathrm{n}=271)$ & Transactional & 70 & 25.8 & 21 & 7.7 & 91 & 33.6 & $\leq 0.001$ \\
& Total & 234 & 86.3 & 37 & 13.7 & 271 & 100.0 & \\
C & Transformational & 191 & 70.5 & 26 & 9.6 & 217 & 80.1 & \\
$(\mathrm{n}=271)$ & Transactional & 42 & 15.5 & 12 & 4.4 & 54 & 19.9 & 0.068 \\
& Total & 233 & 86.0 & 38 & 14.0 & 271 & 100.0 & \\
D & Transformational & 218 & 80.4 & 18 & 6.6 & 236 & 87.1 & \\
$(\mathrm{n}=271)$ & Transactional & 23 & 8.5 & 12 & 4.4 & 35 & 12.9 & 0.533 \\
& Total & 241 & 88.9 & 30 & 11.1 & 271 & 100.0 & \\
E & Transformational & 167 & 61.6 & 31 & 11.4 & 198 & 73.1 & \\
$(\mathrm{n}=271)$ & Transactional & 62 & 22.9 & 11 & 4.1 & 73 & 26.9 & 0.002 \\
& Total & 229 & 84.5 & 42 & 15.5 & 271 & 100.0 & \\
F & Transformational & 180 & 66.4 & 24 & 8.9 & 204 & 75.3 & \\
$(\mathrm{n}=271)$ & Transactional & 52 & 19.2 & 15 & 5.5 & 67 & 24.7 & 0.002 \\
& Total & 232 & 85.6 & 39 & 14.4 & 271 & 100.0 & \\
\hline
\end{tabular}

$\mathrm{p}^{* 1}$ : $\mathrm{p}$-value 
Table 4: Statistics of generic quality indicators in the six studied hospitals in 2012[26]

\begin{tabular}{|c|c|c|c|c|c|c|c|c|c|c|c|c|c|c|c|c|c|c|c|c|c|c|c|c|c|}
\hline \multirow{3}{*}{ 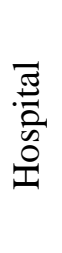 } & \multicolumn{25}{|c|}{ Generic Indicator } \\
\hline & \multicolumn{5}{|c|}{$\begin{array}{l}\text { Percentage of discharge } \\
\text { against medical advice }\end{array}$} & \multicolumn{5}{|c|}{$\begin{array}{c}\text { Percentage of canceled } \\
\text { operations }\end{array}$} & \multicolumn{5}{|c|}{$\begin{array}{l}\text { Number of unscheduled } \\
\text { return for operations }\end{array}$} & \multicolumn{5}{|c|}{$\begin{array}{l}\text { Percentage of length of stay } \\
\text { for appendectomy } \geq 5 \text { days }\end{array}$} & \multicolumn{5}{|c|}{$\begin{array}{l}\text { Percentage of discharge } \\
\text { from surgical department } \\
\text { without operation }\end{array}$} \\
\hline & $\mathrm{Q} 1^{+1}$ & $\mathrm{Q}^{+1}$ & $\mathrm{Q}^{+1}$ & $\mathrm{Q}^{+1}$ & $\mathrm{~A}^{+2}$ & $\mathrm{Q}^{+1}$ & $\mathrm{Q} 2^{+1}$ & $\mathrm{Q}^{+1}$ & $\mathrm{Q}^{4}{ }^{+1}$ & $\mathrm{~A}^{+2}$ & $\mathrm{Q}^{+1}$ & $\mathrm{Q}^{+1}$ & $\mathrm{Q}^{+1}$ & $\mathrm{Q}^{+1}$ & $\mathrm{~A}^{+2}$ & $\mathrm{Q} 1^{+1}$ & $\mathrm{Q}^{+1}$ & $\mathrm{Q}^{+1}$ & $\mathrm{Q}^{+1}$ & $\mathrm{~A}^{+2}$ & $\mathrm{Q}^{+1}$ & ${ }^{1} 2^{+1}$ & $\mathrm{Q}^{+1}$ & $\mathrm{Q}^{+1}$ & $\mathrm{~A}^{+2}$ \\
\hline $\mathrm{A}$ & 4.7 & 6 & 4.2 & - & 5 & 11.3 & 10.7 & 10.8 & 12.4 & 11.3 & 19 & 6 & 13 & 18 & 56 & 16.7 & 15.4 & 29.2 & - & 20.2 & 49.5 & 44.1 & 46.8 & - & 48.8 \\
\hline $\mathrm{B}$ & 1.3 & 1.6 & 0.8 & 0.4 & 1 & 13.6 & 12.7 & 13.3 & 12.1 & 12.9 & 0 & 1 & 13 & 3 & 17 & 35.4 & 18.3 & 17.1 & 22.7 & 23.5 & 45.5 & 40 & 34.8 & 35.8 & 39.2 \\
\hline $\mathrm{C}$ & 5.5 & 3.8 & 4.5 & 5.6 & 4.9 & 10.0 & 6.9 & 8.6 & 12.5 & 9.5 & 0 & 0 & 0 & 9 & 9 & 46.7 & 50.7 & 45.8 & 42.1 & 46.6 & 49.1 & 41.3 & 44.1 & 54.4 & 47.1 \\
\hline $\mathrm{D}$ & 8 & 7.4 & 8 & 6.7 & 7.6 & 9 & 9.2 & 9.1 & 9.8 & 9.3 & 4 & 0 & 6 & 1 & 11 & 10.1 & 13.6 & 17 & 16.2 & 14.1 & 62.8 & 49.6 & 52.5 & 51.2 & 54.5 \\
\hline $\mathrm{E}$ & 2.5 & 2.7 & 2.2 & 1.6 & 2.2 & 12.9 & 10.0 & 11.7 & 14.7 & 12.3 & 8 & 16 & 11 & 13 & 48 & 16.9 & 15 & 11.8 & 15.9 & 14.9 & 33.8 & 28.6 & 33.1 & 33.8 & 32.3 \\
\hline $\mathrm{F}$ & 7.1 & 9.5 & 6.8 & - & 7.9 & 15.2 & 11.4 & 6.5 & 9.4 & 10.4 & 2 & 9 & 5 & 0 & 16 & 39.3 & 37.5 & 24.2 & - & 35.4 & 64.5 & 42.0 & 37.3 & - & 48.1 \\
\hline
\end{tabular}

Table 5: Relationship between generic quality indicators and transformational leadership style of heads of departments in the six studied hospitals

\begin{tabular}{ccc}
\hline Generic quality indicator & \multicolumn{2}{c}{ Heads of departments } \\
& $\begin{array}{c}\mathrm{p}^{* 1} \\
\text { transformational leadership style } \\
\mathrm{r}^{*}\end{array}$ & 0.957 \\
\hline Percentage of discharge against medical advice & -0.03 & 0.468 \\
Percentage of canceled operations & -0.37 & 0.111 \\
Number of unscheduled return for operations & -0.71 & 0.872 \\
Percentage of the length of stay for appendectomy $\geq 5$ days & -0.09 & 0.329 \\
\hline Percentage of discharge from surgical department without operation & 0.49 & \\
\hline
\end{tabular}

$\mathrm{r}^{*}$ : Pearson coefficient $\quad \mathrm{p}^{* 1}$ : $\mathrm{p}$-value 
medRxiv preprint doi: https://doi.org/10.1101/2020.07.15.20154245; this version posted July 16, 2020. The copyright holder for this preprint

(which was not certified by peer review) is the author/funder, who has granted medRxiv a license to display the preprint in perpetuity.

It is made available under a CC-BY-ND 4.0 International license.

\section{DISCUSSION}

The results of the present study reveal that there was a greater frequency of respondent ratings of their hospital culture as transformational than transactional. These findings could be explained by the fact that leaders in the studied hospitals more often displayed a Transformational Leadership style more than a Transactional Leadership style. This likely has a great effect on shaping and preserving the culture of the hospital. The results also indicate that the majority of followers of the department heads, who viewed their leaders as transformational, considered their organisational culture as transformational. This is consistent with the previous findings of many studies that assessed the relationship between transformational leadership style and transformational organisational culture and reported that there were a significant correlation and positive impact with overall transformational leadership practices.[3] Moreover, the transformational leadership style has a positive and significant impact on organisational innovation[27,28] and organisational learning[29,30] which are among the primary components of the essence of the organisational culture.[9] This may also explain how the transformational leadership style indirectly created a transformational culture.

Many studies showed the relationship between transformational leadership style and the quality of care in hospitals.[3,31,32] Because the generic quality indicators of the government health system report the unwanted occurrences -the lower the better-, this study shows that there was an indirect non-significant correlation between the transformational leadership style and most of the indicators included in the study (Table 4). This relationship maybe because of the support and follow up of the transformational leaders to the quality officers of their hospitals who were responsible for the implementation of these generic indicators. Moreover, the characteristics of the transformational leadership style such as influencing, advising, and being attention to followers needs could be factors that lead to the improvement of the followers' performance reflecting the amelioration of quality indicators' statistics of the hospital. The statistically insignificant correlation implies the presence of confounding factors that should be investigated.

Two factors may have contributed to the weak to moderate correlation between the leadership styles and the generic quality indicators. The first one is the fact that these indicators reflect the performance of the whole hospital as one body, while the leadership styles are assigned for each leader alone. The second factor is related to the discrepancies between the self- 
medRxiv preprint doi: https://doi.org/10.1101/2020.07.15.20154245; this version posted July 16, 2020. The copyright holder for this preprint

rating and followers' rating scores, which is associated with a more negative organisational culture. Authors noticed that where leaders rated themselves more positively than their followers, hospital performance, in general, might be affected.[33] To overcome such limitation, studies recommended to train and educate current and future leaders on the leadership topic, its styles, and the effective use of its strengths.[1,2,5,32,34]

\section{Strengths and limitations}

The majority of the published articles identified on the topic of transformational leadership and quality of care assessed nursing leadership style. This study was conducted in multiple centres that represent the country-wide secondary healthcare services and included a relatively large number and professional variety and authority levels of participants. The multimethod study design allowed the exploration of several relationships between different components and subjects. It also facilitated triangulation and a wider view of the topic. Furthermore, it is the first study in Kuwait and the region to report on Transformational Leadership style, the Transformational Organisational Culture, quality of care indicators, and their interrelationships.

However, some limitations must be acknowledged. Although the result of the leadership style is not the subject of this paper, it is worthy to point that the found transformational leadership, which is not nearly so common as the results indicate, may reflect social desirability bias, especially with the $100 \%$ survey response rate. The study did not include private sector hospitals, nor other care delivery settings within the government sector (primary, tertiary, and quaternary healthcare services). The small number of quality of care indicators and the nature of reporting unwanted occurrences did not allow the robust evaluation of the quality of care desired by the authors. In addition, there might be other confounding factors not studied here which resulted in the non-significant indirect correlation between quality indicators and transformational leadership style of leaders. Finally, the study explored the relationship between culture and quality with only one leadership model. This does not permit conclusions about inferiority or superiority of the transformational leadership style over other leadership styles or say anything about how other leadership styles affect culture or outcomes in healthcare organisations.[2,35] 
medRxiv preprint doi: https://doi.org/10.1101/2020.07.15.20154245; this version posted July 16, 2020. The copyright holder for this preprint

\section{Practice implications}

The requirement for continuing education in the healthcare professions makes a learning and transforming culture more desirable. Therefore, training and developing programmes are essential for leaders to develop a strong vision and philosophy to lead, communicate expectations, develop others, and lead healthcare organisations to meet strategic objectives.[1,2,32] This study permits insight into a very rich and important regionally underresearched area. The authors invite researchers to explore and compare the different leadership styles and models. Effective transformational leadership can be improved through training, education, experience, and professional development. The authors desire further collaboration with the quality indicators team to reflect on how to advance the current indicators programme.

\section{CONCLUSIONS}

According to followers' ratings, organisational culture in the six studied hospitals is mostly of transformational with large percentages of followers rating their leader and organisational culture as transformational. Only a few $(8.5 \%)$ of followers in only one hospital found their leader to be transformational but their organisational culture transactional. However, in general, our results in this setting suggest that leaders are shapers and influencers of their organisational culture.

The effect of transformational leadership style on the quality of care delivered by the organisation can be measured using indicators that compare the healthcare organisation's performances to an external reference or "gold standards". Therefore, the relationship between transformational leadership style and quality indicators was measured in this study. There is an indirect and non-significant relationship between generic quality indicators and transformational leadership style of both hospitals' directors and heads of departments. This field should be further explored. 
medRxiv preprint doi: https://doi.org/10.1101/2020.07.15.20154245; this version posted July 16, 2020. The copyright holder for this preprint

(which was not certified by peer review) is the author/funder, who has granted medRxiv a license to display the preprint in perpetuity.

It is made available under a CC-BY-ND 4.0 International license .

\section{REFERENCES}

1 Alloubani A, Akhu-Zaheya L, Abdelhafiz IM, et al. Leadership styles' influence on the quality of nursing care. Int J Health Care Qual Assur 2019;32:1022-33.

doi:10.1108/IJHCQA-06-2018-0138

2 Cope V, Murray M. Leadership styles in nursing. Nurs Stand 2017;31. doi:10.7748/ns.2017.e10836

3 Sfantou DF, Laliotis A, Patelarou AE, et al. Importance of Leadership Style towards Quality of Care Measures in Healthcare Settings: A Systematic Review. Healthcare 2017;5:73. doi:10.3390/healthcare 5040073

4 Asamani JA, Naab F, Ofei AMA, et al. Do leadership styles influence productivity? Br J Healthc Manag 2016;22:83-91. doi:10.12968/bjhc.2016.22.2.83

5 Cummings GG, Tate K, Lee S, et al. Leadership styles and outcome patterns for the nursing workforce and work environment: A systematic review. Int J Nurs Stud 2018;85:19-60. doi:10.1016/j.ijnurstu.2018.04.016

6 Hill B. Does leadership style of modern matrons contribute to safer and more effective clinical services? Nurs Manag (Harrow) 2017;24. doi:10.7748/nm.2017.e1488

7 Thusini S, Mingay J. Models of leadership and their implications for nursing practice. $\mathrm{Br} \mathrm{J}$ Nurs 2019;28:356-60. doi:10.12968/bjon.2019.28.6.356

8 Dixon-Woods M, Baker R, Charles K, et al. Culture and behaviour in the English National Health Service: overview of lessons from a large multimethod study. BMJ Qual Saf 2014;23:106-15. doi:10.1136/bmjqs-2013-001947

9 Robbins SP, Judge TA. Organizational Behavior. 18th ed. New York, NY, USA: : Pearson 2018.

10 Schein EH, Schein PA. Organizational Culture and Leadership. 5th ed. Hoboken, NJ, USA: : John Wiley \& Sons Inc 2017.

11 Gheith NA-R. Reconstructing organization culture through enforcing head nurses transformational leadership style. Aust J Basic Appl Sci 2010;4:1288-96.

12 Tsai Y. Relationship between Organizational Culture, Leadership Behavior and Job Satisfaction. BMC Health Serv Res 2011;11:98. doi:10.1186/1472-6963-11-98

13 Haycock-Stuart E, Kean S. Does nursing leadership affect the quality of care in the community setting? J Nurs Manag 2012;20:372-81. doi:10.1111/j.1365-2834.2011.01309.x

14 Elmontsri M, Almashrafi A, Banarsee R, et al. Status of patient safety culture in Arab countries: a systematic review. BMJ Open 2017;7:e013487. doi:10.1136/bmjopen-2016013487 
medRxiv preprint doi: https://doi.org/10.1101/2020.07.15.20154245; this version posted July 16, 2020. The copyright holder for this preprint

(which was not certified by peer review) is the author/funder, who has granted medRxiv a license to display the preprint in perpetuity.

It is made available under a CC-BY-ND 4.0 International license .

15 WHO. Handbook for national quality policy and strategy: a practical approach for developing policy and strategy to improve quality of care. Geneva, Switzerland: : World Health Organization 2018. https://apps.who.int/iris/bitstream/handle/10665/272357/9789241565561-eng.pdf?ua=1 (accessed 15 Jun 2020).

16 National Academies of Sciences, Engineering, and Medicine. Improving Diagnosis in Health Care. Washington, D.C.: : National Academies Press 2015. doi:10.17226/21794

17 Horvat A, Filipovic J. Healthcare system quality indicators: the complexity perspective. Total Qual Manag Bus Excell 2020;31:161-77. doi:10.1080/14783363.2017.1421062

18 Beaussier A-L, Demeritt D, Griffiths A, et al. Steering by their own lights: Why regulators across Europe use different indicators to measure healthcare quality. Health Policy 2020;124:501-10. doi:10.1016/j.healthpol.2020.02.012

19 Curran CR, Totten MK. Governing for improved quality and patient safety. Nurs Econ 2011;29:38.

20 ALFadhalah T, Elamir H. Exploring leadership styles in government hospitals in Kuwait. Leadersh Health Serv 2019;32:458-76. doi:10.1108/LHS-11-2018-0059

21 Department of Health Information and Medical Record. Health Kuwait. Kuwait: : Ministry of Health 2009.

22 Al-Mailam FF. Transactional Versus Transformational Style of Leadership_-Employee Perception of Leadership Efficacy in Public and Private Hospitals in Kuwait. Qual Manag Healthc 2004;13:278.

23 Daniel WW, Cross CL. Biostatistics: A Foundation for Analysis in the Health Sciences. 10 edition. Hoboken, NJ, USA: : Wiley 2013.

24 Bass BM, Avolio BJ. Organizational description questionnaire: Sampler set. 1st ed. CA, USA: : Mind Garden Inc. 1992.

25 Bass BM, Avolio BJ. Multifactor leadership questionnaire: Manual and sampler set. 3rd ed. CA, USA: : Mind Garden Inc. 2004.

26 Standards and Indicators Department. Generic Quality Indicator Results (Quarter and Annual). Kuwait: : Quality and Accreditation Directorate, Ministry of Health 2012.

27 Hughes DJ, Lee A, Tian AW, et al. Leadership, creativity, and innovation: A critical review and practical recommendations. Leadersh Q 2018;29:549-69.

28 İşcan ÖF, Ersarı G, Naktiyok A. Effect of Leadership Style on Perceived Organizational Performance and Innovation: The Role of Transformational Leadership Beyond the Impact of Transactional Leadership - An Application among Turkish SME's. Procedia - Soc Behav Sci 2014;150:881-9. 
medRxiv preprint doi: https://doi.org/10.1101/2020.07.15.20154245; this version posted July 16, 2020. The copyright holder for this preprint

(which was not certified by peer review) is the author/funder, who has granted medRxiv a license to display the preprint in perpetuity.

It is made available under a CC-BY-ND 4.0 International license.

29 Arachchi C. Transformational leadership and learning organizations. J Adyapana Sanwada04 2012;:71-89.

30 Imran MK, Ilyas M, Aslam U, et al. Organizational learning through transformational leadership. Learn Organ 2016;23:232-48. doi:10.1108/TLO-09-2015-0053

31 Cheng C, Bartram T, Karimi L, et al. Transformational leadership and social identity as predictors of team climate, perceived quality of care, burnout and turnover intention among nurses. Pers Rev 2016;45:1200-16. doi:10.1108/PR-05-2015-0118

32 Lavoie $\square$ Tremblay M, Fernet C, Lavigne GL, et al. Transformational and abusive leadership practices: impacts on novice nurses, quality of care and intention to leave. $J$ Adv Nurs 2016;72:582-92. doi:10.1111/jan.12860

33 Aarons GA, Ehrhart MG, Farahnak LR, et al. Discrepancies in Leader and Follower Ratings of Transformational Leadership: Relationship with Organizational Culture in Mental Health. Adm Policy Ment Health Ment Health Serv Res 2017;44:480-91. doi:10.1007/s10488-0150672-7

34 Fischer SA. Transformational leadership in nursing: a concept analysis. J Adv Nurs 2016;72:2644-53. doi:10.1111/jan.13049

35 Jambawo S. Transformational leadership and ethical leadership: their significance in the mental healthcare system. Br J Nurs 2018;27:998-1001. doi:10.12968/bjon.2018.27.17.998 